\title{
Validations and descriptions of European syntaxa of vegetation dominated by lichens, bryophytes and algae
}

\author{
Helga Bültmann ${ }^{1}$, Claude Roux ${ }^{2}$, José Maria Egea ${ }^{3}$, Philippe Julve ${ }^{4}$, \\ Oliver Bricaud ${ }^{5}$, Giuseppe Giaccone ${ }^{6}$, Lothar Täuscher ${ }^{7}$, Marijke Creveld ${ }^{8}$, \\ Vincenzo Di Martino ${ }^{9}$, Stjepko Golubić ${ }^{10}$ \& Nozomu Takeuchi ${ }^{11}$
}

\begin{abstract}
Bültmann, H., Roux, C., Egea, J.M., Julve, P., Bricaud, O., Giaccone, G., Täuscher, L., Creveld, M., Di Martino, V., Golubić, S. \& Takeuchi, N. Validations and descriptions of European syntaxa of vegetation dominated by lichens, bryophytes and algae. Lazaroa 36: 107-129 (2015).

Fourty-two high-rank syntaxa and seven associations of the thallophyte system of syntaxa are either described as new or validated in this paper. Among those, there are the following nine classes: Aspicilietea candidae, Caulerpetea racemosae, Desmococcetea olivacei, Entophysalidetea deustae, Gloeocapsetea sanguineae, Mesotaenietea berggrenii, Naviculetea gregariae, Porpidietea zeoroidis, Roccelletea phycopsis. Eleven orders and ten alliances as well as three associations are described or validated: the Aspicilietalia verruculosae (incl. Aspicilion mashiginensis and Teloschistion contortuplicati), the Caulerpetalia racemosae (incl. Caulerpion racemosae), the Desmococcetalia olivacei (incl. Desmococcion olivacei), the Dirinetalia massiliensis, the Fucetalia vesiculosi (incl. Ascophyllion nodosi), the Gloeocapsetalia sanguineae, the Lecideetalia confluescentis (incl. Lecideion confluescentis), the Mesotaenietalia berggrenii (incl. Mesotaenion berggrenii, Mesotaenietum berggrenii and Chloromonadetum nivalis), the Naviculetalia gregariae (incl. Oscillatorion limosae and Oscillatorietum limosae), the Porpidietalia zeoroidis (incl. Porpidion zeoroidis), and the Roccelletalia fuciformis (incl. Paralecanographion grumulosae). Further, five orders, seven alliances and four associations, classified in known classes, were described as well. These include: the Bacidinetalia phacodis, the Agonimion octosporae and the Dendrographetalia decolorantis (all in the Arthonio radiatae-Lecidelletea elaeochromae), the Staurothelion solventis (in the Aspicilietea lacustris), the Pediastro duplicis-Scenedesmion quadricaudae and the Pediastro duplicis-Scenedesmetum quadricaudae (both in the Asterionelletea formosae), the Peccanion coralloidis and the Peltuletalia euplocae (both in the Collematetea cristati), the Laminarion hyperboreae, the Saccorhizo polyschidi-Laminarietum and the Alario esculenti-Himanthalietum elongatae (all in the Cystoseiretea crinitae), the Delesserietalia sanguinei, the Delesserion sanguinei and the Delesserietum sanguineae (all in the Lithophylletea soluti), as well as the the Rinodino confragosae-Rusavskietalia elegantis and the Rhizocarpo geographici-Rusavskion elegantis (both in the Rhizocarpetea geographici).
\end{abstract}

Keywords: algal vegetation, bryophyte vegetation, cryptogams, International Code of Phytosociological Nomenclature, lichen vegetation, phytosociology, syntaxonomy, vegetation of Europe.

\footnotetext{
${ }^{1}$ Michaelweg 40, D-48149 Münster, Germany. Email: bultman@uni-muenster.de

2390 chemin des Vignes-Vieilles, F-84120 Mirabeau, France. Email: claude.roux21@wanadoo.fr, claude.roux@lichenologue.org

${ }^{3}$ Departamento de Biología Vegetal, Area de Botánica, Facultad de Biología, Campus Universitario de Espinardo, E-30100 Murcia, Spain. Email: jmegea@um.es

${ }^{4}$ Laboratoire Ecologie et Biodiversité, FGES - Université Catholique de Lille, 83 boulevard Vauban, Espace Saint-Raphäl, Bâtiment G, F-59016 Lille, France. Email: pjulve@icl-lille.fr, philippe.julve@wanadoo.fr

557 rue du mas de Pialon, F-13750 Plan-d’Orgon, France; bricaud.olivier@orange.fr

${ }^{6}$ Dipartimento di Botanica, Università di Catania, Contrada Rini 10, I-90020 Baucina (PA), Italy. Email: gcgiaccone@virgilio.it

${ }^{7}$ Institut für angewandte Gewässerökologie $\mathrm{GmbH}$, Schlunkendorfer Straße 2e, D-14554 Seddiner See, Germany. Email: Lothar.Taeuscher@iag-gmbh.info

${ }^{8}$ The Netherlands. Email: m.creveld@planet.nl

${ }^{9}$ ISAFOM, Consiglio Nazionale Ricerche, OU Catania, Catania, Italy. Email: vincenzo.dimartino@cnr.it

${ }^{10}$ Biological Science Center, Boston University, 5 Cummington str, Boston, MA 02215, USA. Email: golubic@bu.edu

${ }^{11}$ Department of Earth Sciences, Graduate School of Science, Chiba University, 1-33, Yayoicho, Inage-ku, Chiba 263-8522, Japan. Email: ntakeuch@faculty.chiba-u.jp
} 
Resumen: Bültmann, H., Roux, C., Egea, J.M., Julve, P., Bricaud, O., Giaccone, G., Täuscher, L., Creveld, M., Di Martino, V., Golubić, S. \& Takeuchi, N. Descripción y validación de distintos sintáxones europeos de la vegetación dominada por briófitos, líquenes y algas. Lazaroa 36: 107-129 (2015).

Se describen por primera vez o se validan un total de 42 sintáxones de alto rango y 7 asociaciones correspondientes a distintos tipos de vegetación talofítica y briofítica. Entre ellos se incluyen las 9 clases siguientes: Aspicilietea candidae, Caulerpetea racemosae, Desmococcetea olivacei, Entophysalidetea deustae, Gloeocapsetea sanguineae, Mesotaenietea berggrenii, Naviculetea gregariae, Porpidietea zeoroidis, Roccelletea phycopsis. Once órdenes y diez alianzas, además de tres asociaciones pertenecientes a estas clases nuevas, se describen por primera vez o se validan: Aspicilietalia verruculosae (incl. Aspicilion mashiginensis y Teloschistion contortuplicati), Caulerpetalia racemosae (incl. Caulerpion racemosae), Desmococcetalia olivacei (incl. Desmococcion olivacei), Dirinetalia massiliensis, Fucetalia vesiculosi (incl. Ascophyllion nodosi), Gloeocapsetalia sanguineae, Lecideetalia confluescentis (incl. Lecideion confluescentis), Mesotaenietalia berggrenii (incl. Mesotaenion berggrenii, Mesotaenietum berggrenii y Chloromonadetum nivalis), Naviculetalia gregariae (incl. Oscillatorion limosae and Oscillatorietum limosae), Porpidietalia zeoroidis (incl. Porpidion zeoroidis), y Roccelletalia fuciformis (incl. Paralecanographion grumulosae). Además, otros cinco órdenes, siete alianzas y cuatro asociaciones pertenecientes a clases ya descritas se proponen como nuevos: Bacidinetalia phacodis, Agonimion octosporae y Dendrographetalia decolorantis (clase Arthonio radiatae-Lecidelletea elaeochromae); Staurothelion solventis (clase Aspicilietea lacustris); Pediastro duplicis-Scenedesmion quadricaudae y Pediastro duplicis-Scenedesmetum quadricaudae (clase Asterionelletea formosae); Peccanion coralloidis y Peltuletalia euplocae (clase Collematetea cristati); Laminarion hyperboreae, Saccorhizo polyschidi-Laminarietum y Alario esculenti-Himanthalietum elongatae (clase Cystoseiretea crinitae); Delesserietalia sanguinei, Delesserion sanguinei y Delesserietum sanguineae (clase Lithophylletea soluti); y Rinodino confragosae-Rusavskietalia elegantis y Rhizocarpo geographici-Rusavskion elegantis (clase Rhizocarpetea geographici).

Palabras clave: vegetación algal, vegetación briofítica, vegetación liquénica, criptógamas, Código Internacional de Nomenclatura Fitosociológica, fitosociología, sintaxonomía, vegetación de Europa.

\section{INTRODUCTION}

Thallophyte vegetation supposedly had occupied terrestrial habitats long before vascular land plant vegetation evolved (BOMFLEUR \& al., 2010). Vegetation of bryophytes, lichens and algae has been subject of description using the BRAUN-BLANQUET (1964) approach since the early days of the method (e.g. FREY, 1923; HilitZer, 1925; MesSiKOMMER, 1927; OCHSNER, 1928; earlier syntaxonomic surveys by KLIKA \& HADAČ, 1944; KliKA, 1948, KLEMENT, 1955). While the vegetation of bryophytes, lichens and macroalgae is reasonably well known, the vegetation of microalgae has been studied rarely: MARGALEF (1944) studied the vegetation of freshwater algae in Spanish mountains, GoluBIĆ (1967) investigated the vegetation of aerophytic microalgae on calcareous rocks, TÄUSCHER (1998) presented a synopsis for benthic and planctonic freshwater algal vegetation of the lowlands, and KHAYBulLina \& al. (2004, $2005,2005 a)$ described the vegetation of soil algae. Even vegetation of macrofungi has been described that way, however the system of fungal communities remains very rudimentary (e.g. PIRK \& TÜXEN, 1955, 1957; Michael \& al., 1985).

Most monographs deal either with bryophyte, lichen or algae vegetation. Works integrating all thallophyte groups are quite rare (e.g. BARKMAN, 1958). Recent large-scale surveys exist only for bryophyte syntaxa (MARSTALLER, 2006). Still, the thallophyte vegetation is being studied by specialists only, and it has rarely been recognized in vegetation studies. It is often disregarded since it is limited to special habitats and taxonomic expertise is insufficient; usually only a limited number of the larger and more conspicuous terricolous thallophyte species is included in relevé species lists.

The status of the thallophyte communities has been discussed in detail by expert vegetation ecologists familiar with vegetation at different scales (WILMANNS, 1966; BARKMAN, 1973). In particular BARKMAN (1973: 460) analysed different approaches used for vegetation description at different scales. In Dutch juniper scrub he distinguished between microcoena delimited by microhabitat and synusiae that were floristically defined. He proposed to describe the syntaxa synusiae by 
applying the Braun-Blanquet-approach and nomenclature the same way as for the classification of phytocoena. The terms synusia, union and federation for community, association and alliance are still occasionally applied (PAUS, 1997), however always with the agreement that such assemblages should be described according to the rules of the ICPN (WEBER \& al., 2000).

While the terminology of the units has still not been fixed, researchers mostly followed the procedures of the Braun-Blanquet approach: studied relevés and described floristically delimited units for the thallophyte vegetation using the rank-indicating terminations of the ICPN (-etum, -ion, -alia, -etea). Thallophyte syntaxa based on spatially delimitated relevés, classified by floristic criteria and using ranks corresponding to those of the phytocoena are governed by the ICPN (WEBER \& al., 2000: Definition I). Independently, authors found it necessary to distinguish between floristically well-delimited thallophyte coenoses and 'true' synusiae of one-layered stands of few species with identical growth-form occurring within phytocoenoses (e.g. BüLtMANN, 2005 for reindeer lichen stands in the understorey of pine forests; Marstaller, 2006 for the bryophyte vegetation of the Rhytidiadelphion squarrosi Waldheim 1944). Therefore the use of terms of the synusial system for 'good' thallophyte syntaxa seems not advisable anymore. Following BARKMAN (1973), the term micro-communities, micro-associations etc. might be most suitable. In some cases, micro-communities can be very extensive though, e.g. in arctic or mountain regions.

The extensive number of already described thallophyte syntaxa shows that construction of a meaningful syntaxonomic system for the thallophytic vegetation is feasible (see also WiLMANNS, 1998).

The thallophyte communities growing on both natural and artificial rock surfaces are well defined often species-rich. Yet even the most common types have rarely been addresses in syntaxonomic studies because of taxonomic problems, especially the rather time-consuming identification of constituent species.
Epiphytic and epixylic communities depend on chemistry and structure of the bark and wood, but are rarely specific to a tree species. These communities are usually excluded from the studies of forest vegetation. SCHUHWERK (1986) showed a possibility to include thallophytic communities in tables of forest relevés by treating them as 'species'. Unfortunately this useful approach has not been followed by others.

Terricolous thallophytes use the same substrate as vascular plants, but have no roots and are poikilohydric. They grow on the surface or occasionally in the pores of the soil (microalgae). The thallophytes can grow (1) as single thalli or tiny patches within a phytocoenose, (2) as synusiae of single growth form, and (3) as stands of bryophytes, lichens and/or algae in spatially delimitated spots with scarce or no cover of vascular plants and often in gaps in the vegetation. Only the latter have been described as thallophyte syntaxa.

The thallophyte syntaxa of bryophytes, lichens and algae have been compiled for the first Europe-wide checklist of high ranked syntaxa including the bryophyte, lichen and algal syntaxa (EuroVegChecklist: Mucina \& al., in press). This checklist will include 27 classes, 53 orders and 137 alliances of bryophyte and lichen syntaxa and 13 classes, 24 orders and 53 alliances of algal syntaxa (see Table 1 for an overview). Of those syntaxa nine classes, 16 orders and 17 alliances, almost $14 \%$, were not yet validly described according to the ICPN (WeBer \& al., 2000) and therefore are to be described here, alongside with seven new associations.

\section{A NEW ALLIANCE IN THE ASPICILIETEA LACUSTRIS}

The Aspicilietea lacustris Wirth 1972 includes only one order - the Hydroverrucarietalia Èernohorský et Hadaè ex Klement 1955. The vegetation on acidic rocks is rather well studied, but the syntaxa from calcareous substrates are less known. Asta \& al. (1973a) described the Staurotheletum solventis from submerged cal- 
careous rocks of the high-mountain regions of France that cannot be placed within any currently recognised alliance. The Staurothelion solventis is described (see below) to accomodate the aquatic lichen communities on calcareous rocks from high mountains, in addition to the Verrucarion siliceae Wirth 1972, the Aspicilion lacustris Klement 1950, and the Porinion lectissimae Wirth 1980 from acidic substrates. The Staurothelion solventis includes the type association and one provisionally described community (AstA \& al., 1973a).

\section{Staurothelion solventis Roux all. nov. hoc loco}

(Hydroverrucarietalia, Aspicilietea lacustris)

TYPE: Holotypus hoc loco: Staurotheletum solventis Asta, Clauzade et Roux 1973 (AsTA \& al., 1973a: 75-81).

Character taxa of the Alliance: Placynthium tantaleum, Polyblastia ardesiaca, Staurothele sapaudica, S. solvens.

\section{A NEW ORDER AND AN ALLIANCE IN THE RHIZOCARPETEA GEOGRAPHICI}

The species diversity of lichens on siliceous rocks is higher than on any other substrate (BÜltmann, 2010). The Rhizocarpetea geographici Wirth 1972 is a very large class, comprising six orders (Rhizocarpetalia obscurati Wirth 1980, Rhizocarpetalia Klement 1949 nom. conserv. propos., Acarosporetalia sinopicae Creveld 1981, Umbilicarietalia Oberdorfer ex Klika et Hadač 1944, Parmelietalia saxatilis Wirth 1972 and Rinodino confragosaeRusavskietalia elegantis). The latter is a new order comprising sub-nitrophilous lichen communities on subacidic siliceous rocks and on acidic rocks irrigated by calcium-rich water. Characteristic is the combination of acidophytes and nitrophilous neutrophytes, indifferent species and weak basiphytes. Besides the type alliance, the Rhizocarpo-Rusavskion (see below), the order includes also the Lecanorion rubinae Frey 1933 on nutrient enriched tops of bird rocks in the subalpine to nival belts and in the Arctic, and the thermophilous Physcion dimidiatae Wirth 1972.

The validation of the order became necessary because CREVELD (1981) chose the invalidly published Rhizocarpo-Xanthorion Creveld 1981 as the type alliance, hence rendering the order invalidly described as well.

The conspicuous orange stands of Rusavskia elegans (formerly better known as Xanthoria elegans) are typical for sites with a strong influence of bird manure on subacidic and calcareous rocks. Similar communities on calcareous rocks, however, belong in the Verrucarietea nigrescentis.

\section{Rinodino confragosae-Rusavskietalia elegan- tis Creveld ordo nov. hoc loco \\ (Rhizocarpetea geographici)}

VALIDATED NAME: Rinodino confragosaeXanthorietalia elegantis Creveld 1981 (CREVELD, 1981: 87) [ICPN Art. 17] Xanthoria elegans (Link) Th. Fr. is a synonym of Rusavskia elegans. SynONYMS: Neuropogonetalia Mattick 1951 [Art. 2b], Physcietalia caesiae Mattick 1951 p.p. [Art. 2b], Physcietalia Hadač 1962 [Art. 2b], Physcietalia caesiae Mattick ex Creveld 1981 [Art. 17].

Type: Holotypus hoc loco: Rhizocarpo geographici-Rusavskion elegantis Creveld in Bültmann \& al., 2015 (see below).

Character taxa of the ORder: Caloplaca vitellinula, Candelariella vitellina, Myriospora scabrida, Rhizoplaca melanophthalma, Rinodina confragosa.

DIFFERENTIAL SPECIES AGAINST THE OTHER ORDERS ON STRONGLY ACIDIC ROCKS ARE NEUTROPHYTES OR CALCIPHYTES: Candelariella aurella, Lecania erysibe, Lecanora dispersa, Phaeophyscia orbicularis, Placynthium nigrum.

\section{Rhizocarpo geographici-Rusavskion elegantis Creveld all. nov. hoc loco \\ (Rinodino confragosae-Rusavskietalia elegan- tis, Rhizocarpetea geographici)}


VALIDATED NAME: Rhizocarpo-Xanthorion Creveld 1981 (CReveld, 1981: 88) [Art. 3g].

SyNONYMS: Neuropogion melaxathi Mattick 1951 [Art. 2b], Physcion caesiae Mattick 1951 [Art. 2b], Caloplacion elegantis Hadač 1962 [Arts. 2b, 3b], Xanthorion elegantis Dubiel et Olech 1990 [Art. 3b].

TYPE: Holotypus hoc loco: Buellio nivalisXanthorietum elegantis Creveld 1981 (CREVELD, 1981: 89-92, Table II, relevés 1-16).

Character taxon of the alliance: Physcia caesia.

\section{NEW LICHEN SYNTAXA ON CALCIFEROUS SCHISTS AND DECALCIFIED ROCKS IN THE ALPS}

Asta \& Roux (1977) and Roux (1981) described (for the high-rank syntaxa preliminary, hence invalidly) lichen vegetation of calcareous schists and decalcified rocks at high altitudes of the Alps. The Aspicilietea candidae comprises the achionophytic vegetation types with the sub-thermophilous and the subxerophilous order Aspicilietalia verruculosae and the less thermophilous Lecideetalia confluescentis. The Aspicilietalia verruculosae comprises two alliances that differ in the carbonate content of the rock - the Aspicilion mashiginensis (showing low carbonate content) and the Teloschistion contortuplicati (slightly higher or higher carbonate content).

The new class Porpidietea zeoroidis, comprising a new order and alliance, was coined to accommodate chionophytic lichen vegetation.

In the sequel we validate these syntaxa:

Aspicilietea candidae Asta et Roux ex Roux class. nov. hoc loco

VAlidATED NAME: Aspicilietea candidae Asta et Roux 1977 (Asta \& Roux, 1977: 69-70) [Art. 3b].

SynONym: Aspicilietea candidae Asta et Roux in Roux 1981 (Roux, 1981: 133) [Art. 3b].

Type: Holotypus hoc loco: Aspicilietalia verru- culosae Asta et Roux ex Roux in Bültmann et al. 2015 (see below).

Character tAXa of the Class: Acarospora freyi, Aspicilia candida, Lecidea tessellata var. caesia, L. umbonata.

\section{Aspicilietalia verruculosae Asta et Roux ex Roux ordo nov. hoc loco \\ (Aspicilietea candidae)}

VALIDATED NAME: Aspicilietalia verruculosae Asta et Roux 1977 (AstA \& Roux, 1977: 69-70) [Art. 3b].

Synonym: Aspicilietalia verruculosae Asta et Roux in Roux 1981 (Roux, 1981: 134) [Art. 3b]. TYPE: Holotypus hoc loco: Aspicilion mashiginensis Asta et Roux ex Roux in Bültmann et al. 2015 (see below).

CHARACTER TAXA OF THE ORDER: Aspicilia polychroma subsp. polychroma chemotype verruculosa, Caloplaca anchon-phoeniceon, C. insularis.

\section{Aspicilion mashiginensis Asta et Roux ex Roux all. nov. hoc loco}

(Aspicilietalia verruculosae, Aspicilietea candidae)

VALIDATED NAME: Aspicilion mastrucatae Asta et Roux 1977 (AsTA \& Roux, 1977: 69-70) [Art. 3b]. SYNONYM: Aspicilion mastrucatae Asta et Roux in Roux 1981 (Roux, 1981: 134) [Art. 3b] $A$. mastrucata auct. non (Wahlenb.) Th. Fr. is a synonym of Aspicilia mashiginensis.

TYPE: Holotypus hoc loco: Lecanoretum albulae Asta et Roux 1977 (AstA \& Roux, 1977: 55, Table 20 on pp. 58-59).

Character taxa OF the Alliance: Acarospora hospitans, A. impressula, Aspicilia mashiginensis, A. permutata.

Teloschistion contortuplicati Roux all. nov. hoc loco

(Aspicilietalia verruculosae, Aspicilietea candidae)

TYPE: Holotypus hoc loco: Teloschistetum contortuplicati Asta et Roux 1977 (AsTA \& Roux, 1977: 
39; Table 11 on pp. 42-43). Teloschistes contortuplicatus (Ach.) Clauzade \& Rondon, is often listed as Seirophora contortuplicata (Ach.) Frödén, in Frödén \& Lassen, however the separation from Teloschistes has not been confirmed yet.

Character taXa of the alliance: Acarospora freyi, A. scabra, Carbonea atronivea, Diplotomma dispersum, Lecanora diaboli, Polysporina pusilla, Teloschistes contortuplicatus.

\section{Lecideetalia confluescentis Roux ordo nov. hoc loco \\ (Aspicilietea candidae)}

Type: Holotypus hoc loco: Lecideion confluescentis Roux in Bültmann et al. 2015 (see below). CHARACTER TAXA OF THE ORDER: Bellemerea subcandida, Farnoldia micropsis, Thelidium ungeri, Verrucaria fischeri (syn. V. tristis (Massal.) Krempel.)

\section{Lecideion confluescentis Roux all. nov. hoc loco}

(Lecideetalia confluescentis, Aspicilietea candidae)

Type: Holotypus hoc loco: Lecideetum confluescentis Asta et Roux 1977 (AstA \& Roux, 1977: 33; Table 7 on pp. 34-35).

ChARACTER TAXA OF THE ALliAnCE: Lecanora dispersoareolata, Lecidea confluescens, L. leprosolimbata, $L$. speirodes.

\section{Porpidietea zeoroidis Roux class. nov. hoc loco}

TyPe: Holotypus hoc loco: Porpidietalia zeoroidis Asta et Roux ex Roux in Bültmann et al. 2015 (see below).

Character tAXA OF tHE ClAss: Adelolecia kolaensis, Polyblastia cupularis var. cupularis, Porpidia zeoroides, Rhizocarpon petraeum.

\footnotetext{
Porpidietalia zeoroidis Asta et Roux ex Roux ordo nov. hoc loco

(Porpidietea zeoroidis)
}

Type: Holotypus hoc loco: Porpidion zeoroidis Asta et Roux ex Roux all. nov. (see below).

CHARACTER TAXA OF THE ORDER: Adelolecia kolaensis, Polyblastia cupularis var. cupularis, Porpidia zeoroides, Rhizocarpon petraeum.

\section{Porpidion zeoroidis Asta et Roux ex Roux all. nov. hoc loco}

(Porpidietalia zeoroidis, Porpidietea zeoroidis)

VALIDATED NAME: Huilion macrocarpaetrullisatae Asta et Roux 1977 (AsTA \& Roux, 1977: 69-70) [Art. 3b].

SYNONYM: Huilion macrocarpae-trullisatae Asta et Roux in Roux 1981 (Roux, 1981: 135, 137-138) [Art. 3b] Huilia macrocarpa (DC.) Hertel var. trullisata (Arnold) Hertel is a synonym of Porpidia zeoroides.

TYPE: Holotypus hoc loco: Stenhammarelletum turgidae Hertel ex Asta, Clauzade et Roux 1973 (AsTA \& al., 1973b: 547-563, Table 1, rel. 1-8; subassociation of Stenhamarella turgida $=$ Stenhammarelletum turgidae sensu Asta et Roux 1977) The group of relevés named 'subassociation of Lecidea confluescens' in 1973 was reclassified as the Lecideetum confluescentis and classified in the Aspicilietea candidae by AstA \& Roux (1977).

Character taXA OF THE Alliance: Adelolecia kolaensis, Polyblastia cupularis var. c., Porpidia zeoroides, Rhizocarpon petraeum

\section{VALIDATION OF SYNTAXA OF JELLY LICHENS ON LIMESTONE AND BASE-RICH ROCKS}

The Collematetea cristati Wirth 1980 is a class of cyanobacterial lichen communities on calcareous or base-rich rocks, dominated by jelly lichens. This growth form can accumulate the occasional supply of seepage water and become swollen and jelly-like when wet. The Collematetalia cristati Wirth 1980 comprises vegetation on limestone with the thermophilous Peccanion coralloidis in well illuminated and the Collemation tuniformis Klement 1955 corr. Wirth 1980 in shaded habitats. The other order, the Peltuletalia euplocae (com- 
prising the Peltulion euplocae Llimona et Egea 1984) accomodates the jelly lichen syntaxa on base-rich siliceous rocks.

\section{Peccanion coralloidis Moreno et Egea ex Egea all. nov. hoc loco}

(Collematetalia cristati, Collematetea cristati)

VAlidATED NAME: Peccanion coralloides Moreno et Egea 1991 (Moreno \& EgEA, 1991: 74) [Art. 3b].

SyNONYMS: Dermatocarpion miniati Mattick 1951 p.p. [Art. 2b], Psorotichion schaereri Wirth 1995 [Art. 3b].

TyPE: Holotypus hoc loco: Peccanio coralloidis-Thyreetum pulvinatae Nowak 1960 (NowaK, 1960: 367-370, Table 16).

CHARACTER taXA OF THE ALliance: Anema decipiens, A. nummularium, Lichinella iodopulchra, Metamelanena caesiella, Peccania coralloides, Placynthium subradiatum, Psorotichia diffracta, P. frustulosa, P. schaereri, Pterygiopsis affinis, Thyrea girardii.

\section{Peltuletalia euplocae Morena et Egea ex Egea ordo nov. hoc loco \\ (Collematetea cristati)}

VAlidATED NAME: Peltuletalia euplocae Llimona et Egea 1985 (Llimona \& EgEA, 1985: 443) [Art. 3b].

SynONYM: Peltuletalia euplocae Morena et Egea 1991 (Moreno \& EgEA, 1991: 74) [Art. 3b].

Type: Holotypus hoc loco: Peltulion euplocae Llimona et Egea 1985 (LLIMONA \& EgEA, 1985: 433-443).

Character taXa of THE ORDER: Collema ryssoleum, Lichinella cribellifera, Peltula euploca, P. omphaliza, P. placodizans.

The holotype Peltulion euplocae Llimona et Egea 1985 is a later homonym of the Peltulion euplocae Llimona et Egea 1984 (LLimONA \& EGEA, 1984: 92). We have decided to follow Moreno \& EgEA (1991) and chose the younger homonym as the type for the Peltuletalia.

\section{VALIDATION OF THE ROCCELLETEA PHYCOPSIS, WITH NEW ORDERS AND AN ALLIANCE}

The ombrophobic and aerohygrophilous rock lichen communities of this class are supported by calcareous to subacidic substrates, found in rather well-illuminated rock overhangs. The class is optimally developed in Southern Europe, Macaronesia and North Africa. It includes conspicuous stands of large fruticose Roccella species, several of them formerly harvested for the production of dye. Syntaxa from carbonate rocks are classified in the Dirinetalia massiliensis, with one alliance - the Roccellion phycopsis Egea et Llimona 1984, those from subacidic to subneutral rocks in the order Roccelletalia fuciformis (with the moderately aero-hygrophilous Paralecanographion grumulosae and the highly aero-hygrophilous Roccellion Klement 1965).

\section{Roccelletea phycopsis Egea class. nov. hoc loco}

VALIDATED NAME: Roccelletea phycopsis Egea 1989 (EGEA, 1989: 112) [Art. 3b].

SynONYMS: Physcietea Mattick 1951 p.p. [Art. 2b], Physcietea Tomaselli 1956 [Art. 2b], Roccelletea phycopsis Follmann 1993 [Art. 3b]. TYPE: Holotypus hoc loco: Dirinetalia massiliensis Egea in Bültmann et al. 2015 (see below).

CHARACTER TAXA OF THE ClASS: Alyxoria subelevata, Dirina massiliensis morphotype sorediata, Roccella phycopsis, Thelopsis isiaca.

\section{Dirinetalia massiliensis Egea ordo nov. hoc loco}

(Roccelletea phycopsis)

Validated name: Dirinetalia massiliensis Egea 1989 (EGEA, 1989: 112) [Art. 3b].

SYNONYMS: Roccelletalia vicentinae Follmann 1993 p.p. [Art. 3b].

TYPE: Holotypus hoc loco: Roccellion phycopsis Egea et Llimona 1984 (EgEA \& LLimonA, 1984: 210). 
Character tAXA OF THE ORDER: Aloxyria mougeotii, A. variiformis, Dirina massiliensis morphotype massiliensis.

Roccelletalia fuciformis Egea ordo nov. hoc loco

(Roccelletea phycopsis)

VALIDATED NAME: Roccelletalia fuciformis Egea 1989 (EGEA, 1989: 113) [Art. 3b].

SynONyms: Physcietalia caesiae Mattick 1951 p.p. [Art. 2b], Roccelletalia vicentinae Follmann 1993 p.p. [Art. 3b].

TYPE: Holotypus hoc loco: Roccellion Klement 1965 (KLEMENT, 1965: 516).

CHARACTER SPECIES OF THE ORDER: Roccella fuciformis, $R$. tinctoria, $R$. tuberculata.

Paralecanographion grumulosae Egea all. nov. hoc loco

(Roccelletalia fuciformis, Roccelletea phycopsis)

VALIDATED NAME: Lecanactidion monstrosae Egea 1989 (EGEA, 1989: 113) [Art. 3b] Lecanactis monstrosa Bagl. = Lecanactis grumulosa (Dufour) Fr. var. monstrosa (Bagl.) Grummann on acidic substrate had been separated from the more basiphytic var. grumulosa, but is now included in Paralecanographa grumulosa.

TyPE: Holotypus hoc loco: Lecanactino monstrosae-Dirinetum insulanae Egea 1989 (EGEA, 1989: 114, 138-140).

Character SPECIES OF THE ALliance: Lecanographa dialeuca, Opegrapha cesareensis, O. lutulenta, Paralecanographa grumulosa, Roccellographa circumscripta.

\section{TWO NEW ORDERS AND AN ALLIANCE}

IN THE ARTHONIO RADIATAE-

\section{LECIDELLETEA ELAEOCHROMAE}

The Arthonio-Lecidelletea comprises epiphytic communities dominated mostly by crustose lichens growing on smooth tree bark with a neutral to moderately acidic bark $\mathrm{pH}$. The Graphidetalia scriptae Hadač in Klika et Hadač 1944 (with two alliances) occur on very smooth bark, beech in particular, in moderately humid sites; the Bacidinetalia phacodis (with one alliance - the Agonimion octosporae) on more porose bark of older trees in shaded and humid situations, and the Dendrographetalia decolorantis (with the Lecanactidion patellarioidis Crespo ex Giralt 1996) occur in rather dry habitats and has southern distribution.

\section{Bacidinetalia phacodis Bricaud et Roux ordo nov. hoc loco \\ (Arthonio radiatae-Lecidelletea elaeochromae)}

VALIDATED NAME: Bacidietalia phacodis Bricaud et Roux 2004 (BRICAUD, 2004: 25, 211) [Art. 3b].

TYPE: Holotypus hoc loco: Agonimion octosporae Bricaud et Roux in Bültmann et al. 2015 (see below).

CHARACTER TAXA OF THE ORDER: Bacidia fraxinea, Bacidina phacodes, non-lichenised fungi: Aleurodiscus disciformis, Dendrominia dryina, Didymosphaeria rubicola, Septobasidium quercinum.

\section{Agonimion octosporae Bricaud et Roux all.} nov. hoc loco

(Bacidietalia phacodis, Arthonio radiataeLecidelletea elaeochromae)

Validated name: Agonimion octosporae Bricaud et Roux 2004 (BRICAUd, 2004: 43-44, 311) [Art. 3b].

SYNONYM: Bacidion rubellae Wirth 1995 [Art. 3b]. TyPe: Holotypus hoc loco: Hypocenomycetum stoechadianae Abbassi Maaf et Roux 1987 (ABbassi MaAF \& Roux, 1987: 219-227, Table on pp. 224-227).

CHARACTER TAXA OF THE ALLIANCE: Bacidia rubella, Biatoridium monasteriense, Coenogonium luteum, Gyalecta derivata, G. flotowii, G. liguriensis, Navicella pileata (nonlichenised fungus), Thelopsis rubella. 
Dendrographetalia decolorantis Bricaud et Roux ordo nov. hoc loco

(Arthonio radiatae-Lecidelletea elaeochromae)

VALIDATED NAME: Schismatommetalia decolorantis Bricaud et Roux 2004 (BRICAUD, 2004: 43, 91, 311) [Art. 3b] Schismatomma decolorans (Turner et Borrer ex Sm.) Clauzade et Vìzda is a synonym of Dendrographa decolorans.

SynONYMS: Lecanoretalia sienae Crespo 1981 p.p. [Art. 1], Lecanoretalia sienae Crespo ex Crespo et Bueno 1984 p.p. [Art. 2b], Lecanoretalia sienae Crespo ex Giralt 1996 p.p. [Art. 5], Lecanoretalia sienae Crespo ex Boqueras 2000 p.p. [Art. 2b].

TYPE: Holotypus hoc loco: Lecanactidion patellarioidis Crespo ex Giralt 1996 (GIRALT, 1996: 423, 426-427).

ChARACTER TAXA OF THE ORDER: Bactrospora patellarioides, Dendrographa decolorans.

(Lecanactis patellarioides (Nyl.) Vain. is a synonym of Bactrospora patellarioides).

GIRALT (1996) adopted the concept of the name by using Lecanactidion patellarioidis Crespo 1981 ined. (not effectively published). By adopting the name with only one valid association - the Dirinetum ceratonie Klement 1965 (=type), and by listing characteristic species, the name Lecanactidion patellarioidis had been validated by GiRALt (1996).

\section{VALIDATION OF THE NAVICULETEA WITH AN ORDER AND ALLIANCE FOR BENTHIC MICROALGAL COMMUNITIES IN FRESH AND BRACKISH WATERS}

The Naviculetea was proposed by PANKOW (1980) as a provisional class and the order Naviculetalia Pankow 1980 was invalidly published because it was not possible to establish which of several Navicula species in the original diagnosis of the syntaxon name served as the eponymous taxon name.

The order includes the Oscillatorion limosae (cyanobacterial and diatom communities in eutrophic and brackish lowland waters), the
Melosirion variantis Margalef 1951 (syn. Meridio circularis-Naviculion gregariae M. Schlüter 1961) comprising benthic diatom communities in eutrophic or brackish lowland waters, and the Cymbello-Synedrion capitatae M. Schlüter 1961 comprising benthic diatom communities of small eutrophic lowland ponds. In addition, at least nine alliances were described by MARGALEF $(1949,1950,1951)$ for the benthic algae communities in Spanish mountains for a variety of water chemistries. It may well be that new orders or classes for those communities should be defined in future. Those alliances of MARGALEF (l.c.) were tentatively included in the Naviculetalia (Naviculetea).

\section{Naviculetea gregariae Pankow ex Täuscher class. nov. hoc loco}

VALIDATEd NAME: Naviculetea Pankow 1980 (PANKow, 1980: 136) [Art. 3b, 3g].

SynONym: Naviculetea Pankow ex Täuscher 1998 (TÄUSCHER, 1998: 631) [Art. 2b, 3g].

TYPE: Holotypus hoc loco: Naviculetalia gregariae Pankow ex Täuscher in Bültmann et al. 2015 (see below).

CHARACTER TAXA OF THE CLASS: Achnanthes brevipes, Amphora coffaeiformis, A. ovalis, Anomoeoneis sphaerophora, Aphanothece stagnina, Brebissonia boeckii, Caloneis amphisbaena, Calothrix scopulorum, Cocconeis placentula, Coleofasciculus chthonoplastes, Diatoma vulgaris, Ellerbeckia arenaria, Gomphonema parvulum, Lyngbya aestuarii, Melosira varians, Meridion circulare, Microcoleus autumnalis, Navicula salinarum, N. tripunctata, Oscillatoria limosa, Planothidium lanceolatum, Rhoicosphenia abbreviata, Rivularia nitida, Spirulina subsalsa, Tryblionella hungarica, Ulnaria ulna.

\section{Naviculetalia gregariae Pankow ex Täuscher ordo nov. hoc loco \\ (Naviculetea gregariae)}

Validated name: Naviculetalia Pankow 1980 (PANKOW, 1980: 136) [Art. 3g]. 
SynONYMS: Tribonemetalia Margalef 1960 [Art. 2b], Amphipleuretalia Margalef 1960 [Art. 2b], Euastretalia Margalef 1960 [Art. 2b], Naviculetalia Pankow ex Täuscher 1997 (TÄUSCHER, 1997: 13) [Arts. 2b, 3g], Naviculetalia Pankow ex Täuscher 1998 (TÄUSCHER, 1998: 631) [Art. 3g].

TYPE: Holotypus hoc loco: Meridio-Naviculion gregariae M. Schlüter 1961 (SCHLÜTER, 1961: 585-586, 606 \& Table 2 on pp. 573-579).

CHARACTER TAXA OF THE ORDER: the same taxa as for the Naviculetea gregariae (see above).

\section{Oscillatorion limosae Täuscher all. nov. hoc loco}

(Naviculetalia gregariae, Naviculetea gregariae)

VALIDATED NAME: Oscillatorion Möller 1977 (MÖLLER, 1977: 62) [Art. 1].

SynONyms: Oscillatorion Prát in Klika et Hadač 1944 [phantom], Limoseto-Diatomeion Fetzmann 1956 [Arts. 2c, 3b], Oscillatorion Möller et Pankow 1981 (Möller \& PANKow, 1981: 321) [Art. 2b], Oscillatorion Täuscher 1998 (TÄUSCHER, 1998: 631) [Art. 2b].

TYPE: Holotypus hoc loco: Oscillatorietum limosae Möller et Pankow ex Täuscher in Bültmann et al. 2015 (see below).

Character taXa of the Alliance: Microcoleus autumnalis, Oscillatoria limosa, O. tenuis, Phormidium chalybeum, Pseudanabaena limnetica, Spirulina subsalsa.

Oscillatorietum limosae Möller \& Pankow ex Täuscher ass. nov. hoc loco

(Oscillatorion limosae, Naviculetalia gregariae, Naviculetea gregariae)

VALIDATED NAME: Oscillatorietum limosae Möller et Pankow 1981 (Möller \& PANKow, 1981: 318-319) [Art. 5].

SynONYMS: Schlamm-Oscillatorietum Kurz 1922 [Art. 2b], Oscillatorietum limosae Prát ex Klika et Hadač 1944 [Art. 2b].

TYPE: Holotypus hoc loco: Möller \& Pankow (1981: 318. Table 8, relevé 7).
Character TAXA OF THE ASSOCIATION: Oscillatoria limosa, O. tenuis, Phormidium chalybeum, Pseudanabaena limnetica.

\section{A NEW ALLIANCE AND ASSOCIATION IN THE ASTERIONELLETEA FORMOSAE}

The Asterionelletea formosae and the Asterionelletalia formosae were described in a thesis multiplied by hectograph (TÄUSCHER, 1981), which is not effectively published according to ICPN Art. 1 (WEBER \& al., 2000). The syntaxon names have been used in several publications (e.g. Täuscher, 1995), but presumed as valid and never unintentionally validated until Täuscher (1998) described the class and the order by listing only one valid alliance Asterionellion Möller et Pankow 1981. MÖLleR \& PANKOW (1981) validated the alliance by listing only one valid association (Fragilario crotonensis-Asterionelletum gracillimae Messikommer 1927), which they proposed to rename to Fragilario crotonensisAsterionelletum formosae because Asterionella gracillima (Hantzsch) Heiberg is a synonym of A. formosa. According to Möller \& PANKOW (1981) the epithet of the alliance should read 'formosae'.

The class and the order include the three alliances, such as the Asterionellion formosae Möller et Pankow 1981 (communities dominated by diatoms), the Aphanizomeno floris-aquaeMicrocystion aeruginosae Täuscher 1995 (dominated by cyanobacteria), and the Pediastro duplicis-Scenedesmion quadricaudae (dominated by green microalgae).

\section{Pediastro duplicis-Scenedesmion quadricau- dae Täuscher all. nov. hoc loco \\ (Asterionelletalia formosae, Asterionelletea for- mosae)}

VAlidated NAme: Pediastro-Scenedesmion Täuscher 1981 (TÄUSCHER, 1981: 93) [Art. 1]. Synonyms: Pediastro-Scenedesmion Täuscher 1995 (TÄUSCHER, 1995: 5) [Arts. 2b, 3g], 
Pediastro-Scenedesmion Täuscher

1998

(TÄUSCHER, 1998: 631) [Arts. 2b, 3g].

TyPe: Holotypus hoc loco: Pediastro duplicisScenedesmetum quadricaudae Täuscher in Bültmann et al. 2015 (see below).

CHARACTER TAXA OF THE ALLIANCE: Actinastrum hantzschii, Closterium limneticum, Micractinium pusillum, Mucidosphaerium pulchellum, Pandorina morum, Pediastrum duplex, Scenedesmus quadricauda.

\section{Pediastro duplicis-Scenedesmetum quadricau-} dae Täuscher ass. nov. hoc loco

(Pediastro duplicis-Scenedesmion quadricaudae, Asterionelletalia formosae, Asterionelletea formosae)

VAlidated NAME: Pediastro-Scenedesmetum Täuscher 1995 (TÄUSCHER, 1995: 8) [Arts. 2b, 3g]. TYPE: Holotypus hoc loco: TÄUSCHER (1995: 8. Table 1 consists of one relevé, which is the holotype).

Character taXa OF THE ASSOciation: Pediastrum duplex, Scenedesmus quadricauda.

\section{A NEW CLASS AND ORDER FOR THE VEGETATION OF AEROPHYTIC MICROAL- GAL FILMS ON CALCAREOUS ROCKS}

GoluBIĆ (1967) described nine associations of vegetation of rock algae in the Dinarides in the alliance Gloeocapsion sanguineae Golubic 1967. Weak floristic relations link those communities to the syntaxa of benthic aquatic algae, but the strong differences made it impossible to classify the aerophytic rock algae communities to the Naviculetea, and thus a new class and new order have to be described.

Gloeocapsa sanguinea is a widely distributed cyanobacterium, which is typical for moist surfaces of calcareous substrates, e.g. in the black patina or tintenstrichen on rocks, cement walls and monuments (e.g. SAMAD \& ADHIKARY, 2008; Golubić \& al., 2015) or in the 'lampenflora' in Karst caves (MULEC \& Kosi, 2009). It is also known as a photobiont in lichens (BÜDEL \& HeNSSEN, 1988).

\section{Gloeocapsetea sanguineae Bültmann \& Golubić class. nov. hoc loco}

TYPE: Holotypus hoc loco: Gloeocapsetalia sanguineae Bültmann et Golubić in Bültmann et al. 2015 (see below).

CHARACTER TAXA OF THE ClASS: Gloeocapsa biformis, G. compacta, G. kuetzingiana, G. sanguinea, Schizothrix heufleri, Scytonema myochrous.

\section{Gloeocapsetalia sanguineae Bültmann \& Golubić ordo nov. hoc loco \\ (Gloeocapsetea sanguineae)}

TYPE: Holotypus hoc loco: Gloeocapsion sanguineae Golubić 1967 (Golubić, 1967: 165166. Tables $13 \& 14)$.

CHARACTER TAXA OF THE ORDER: the same taxa as for the Gloeocapsetea sanguineae (see above).

\section{A NEW CLASS, ORDER AND ALLIANCE FOR THE GREEN ALGAE FILMS ON BARK AND ACIDIC ROCKS}

The species composition of biofilms of green algae was studied frequently in context of biodeterioration, however rarely using phytosociological methods. It is therefore, that the alliance Schizogonion cruenti Ochsner 1928, containing described three associations (Pleurococcetum vulgaris, Schizogonietum crenulatae and Trentepohlietum abietinae; all nomina nuda) remained a nomen nudum since it had been suggested by OCHSNER (1928).

One species common in those biofilms is Desmococcus olivaceus, which is often listed as one of its synonyms such as Desmococcus viridis (C. Agardh) P.C. Silva, Desmococcus vulgaris F. Brand, Pleurococcus viridis (C. Agardh) Rabenh. or Pleurococcus vulgaris Nägeli (LAUNDON, 1985). Apatococcus lobatus (Chodat) J.B. Petersen is another common species of the green algal films (e.g. BRAND, 1925; BARKMAN, 1958), and GÄRTNER \& 
INGOLIĆ (1989); GÄRTNER (1994) proposed to replace the name Pleurococcetum vulgaris with the Apatococcetum lobati but never supported their proposal with a publication of relevés showing that Apatococcus lobatus is more frequent than Desmococcus olivaceus. Other authors found Desmococcus in equal or higher abundance than Apatococcus (RINDI \& GUIRY, 2003; RINDI, 2007). It is possible, that Desmococcus prefers moister sites and it is more common in the Atlantic Europe, while Apatococcus prefers continental areas and drier habitats (Gustavs, 2010). The Desmococcion olivacei comprises the two validly published associations, such as the Pleurococcetum vulgaris Schorler ex Barkman 1958 dominated by water-repellent coccoid green algae and the Prasiloletum crispae Knebel ex Barkman 1958, dominated by filamentous algae. (Schizogonium crenulatum (Kütz.) Gay is a synonym of Prasiola crispa (Lightfoot) Kützing.)

\section{Desmococcetea olivacei Bültmann class. nov. hoc loco}

Type: Holotypus hoc loco: Desmococcetalia olivacei Bültmann in Bültmann et al. 2015 (see below). CHARACTER TAXA OF THE CLASS: Apatococcus lobatus, Desmococcus olivaceus, Klebsormidium flaccidum, Porphyridium purpureum, Prasiola crispa, Rosenvingiella radicans, Schizogonium murale, Trentepohlia abietina, Trentepohlia umbrina.

\section{Desmococcetalia olivacei Bültmann ordo nov. hoc loco}

(Desmococcetea olivacei)

Type: Holotypus hoc loco: Desmococcion olivacei Bültmann in Bültmann et al. 2015 (see below). CHARACTER TAXA OF THE ORDER: the same taxa as for the Desmococcetea olivacei (see above).

\section{Desmococcion olivacei Bültmann all. nov. hoc loco \\ (Desmococcetalia olivacei, Desmococcetea oli- vacei)}

Type: Holotypus hoc loco: Pleurococcetum vulgaris Schorler ex Barkman 1958 (BARKMAN, 1958: 341).

SYNONYMS: Schizogonion cruenti Ochsner 1928 (OCHSNER, 1928: 47) [Art. 2b], Schizogonion cruenti Ochsner in Klika et Hadač 1944 [Art. $2 b]$.

CHARACTER TAXA OF THE ALLIANCE: the same taxa as for the Desmococcetea olivacei (see above).

\section{MESOTAENIETEA BERGGRENII - A NEW CLASS AND SUBORDINATE SYNTAXA FOR SNOW ALGAE}

KLIKA \& HaDAČ (1944) proposed the Sphaerellion nivalis Hadać in Klika \& Hadač 1944 for the snow algae syntaxa, yet this name remained a nomen nudum. The vegetation and habitat of the snow algae is so unique, that the vegetation could not be placed in any existing class. Communities of snow and ice algae have been studied in Antarctica (e.g. FogG, 1967) to Alaska (e.g. TAKEUCHI, 2001). Besides strong floristic difference depending on the growth on permanent snow or ice as the substrate (e.g. KoL, 1942), further variations have been observed with altitude and ecoregion (TAKEUCHI, 2013). The evaluation of samples, which are equivalent to relevés (KoL, 1942; FoGG, 1967; TAKEUCHI, 2001), suggests at least two associations, such as the Mesotaenietum berggrenii for ice algae and the Chloromonadetum nivalis for snow algae, both are described here based on samples from Alaska.

Chlamydomonas nivalis is the collective name for algae responsible for the red snow and this taxonomic concept was used to describe (invalidly) the Chlamydomonadetum nivalis (PANKOW \& al., 1991). However since the taxonomy of this 'species' is not clear (e.g. Remias \& al., 2013) another characteristic species, the ice alga Mesotaenium berggrenii, was chosen to give the name to class, order and alliance. 
Mesotaenietea berggrenii Bültmann et Takeuchi class. nov. hoc loco

TyPe: Holotypus hoc loco: Mesotaenietalia berggrenii Bültmann et Takeuchi in Bültmann et al. 2015 (see below).

CHARACTER TAXA OF THE ClASs: Ancylonema nordenskioldii, Chlamydomonas nivalis, Chloromonas nivalis, Cryocystis brevispina, Desmotetra antarctica, Mesotaenium berggrenii, Raphidonema nivale.

\section{Mesotaenietalia berggrenii Bültmann et Takeuchi ordo nov. hoc loco (Mesotaenietea berggrenii)}

TyPe: Holotypus hoc loco: Mesotaenion berggrenii Bültmann et Takeuchi in Bültmann et al. 2015 (see below).

CHARACTER TAXA OF THE ORDER: Ancylonema nordenskioldii, Chlamydomonas nivalis, Chloromonas nivalis, Mesotaenium berggrenii, Raphidonema nivale.

\section{Mesotaenion berggrenii Bültmann et Takeuchi all. nov. hoc loco \\ (Mesotaenietalia berggrenii, Mesotaenietea berggrenii)}

Type: Holotypus hoc loco: Mesotaenietum berggrenii Bültmann et Takeuchi in Bültmann et al. 2015 (see below).

SYNONYMS: Sphaerellion nivalis Hadač in Klika et Hadač 1944 [2b], Sphaerellion nivalis Hadač ex Klika 1948 [Art. 2b], Sphaerellion nivalis Hadač 1962 [Art. 2b].

Character taXa of the ALLIANCE: the same taxa as for the Mesotaenietalia berggrenii (see above).

Mesotaenietum berggrenii Bültmann et Takeuchi ass. nov. hoc loco

(Mesotaenion berggrenii, Mesotaenietalia berggrenii, Mesotaenietea berggrenii)
Type: Holotypus hoc loco: TAKEUCHI (2001: 3452. Table I, sample 5, Alaska): Mesotaenium berggrenii 20371 cells, Ancylonema nordenskioldii 6439 cells/ml, Chlamydomonas nivalis 487 cells $/ \mathrm{ml}$, Cylindrocystis brebissonii 243 cells $/ \mathrm{ml}$, Raphidonema sp. 54 cells $/ \mathrm{ml}$, Oscillatoriaceae spec. 134330 cells/ml, Osc. spec. 216177 cells/ml.

CHARACTER TAXA OF THE ASSOCIATION: Ancylonema nordenskioldii, Mesotaenium berggrenii.

\section{Chloromonadetum nivalis Bültmann et} Takeuchi ass. nov. hoc loco

(Mesotaenion berggrenii, Mesotaenietalia berggrenii, Mesotaenietea berggrenii)

TyPe: Holotypus hoc loco: Kol (1942: Sample 35, Alaska, Thompson Pass, red snow, abundance and species data on pages 17, 19, 20, 21, 23, 27): Smithsonimonas abbotii very abundant, Chlamydomonas nivalis abundant, Chloromonas nivalis abundant, Gloeocapsa sanguinea (incl. G. ralfsii (Harvey) Lemmermann) not rare, Mycacanthococcus cellaris f. antarcticus rare, Protoderma cohaerens rare, Raphidonema brevirostre rare, Raphidonema nivale rare.

SYNONYMS: Chlamydomonadetum nivalis Gams 1927 [Art. 2b], Chlamydomonadetum nivalis Gams 1936 [Art. 2b], Chlamydomonadetum nivalis Pankow et al. 1991 [Art. 2b].

CHARACTER TAXA OF THE ASSOCIATION: Chlamydomonas nivalis, Chloromonas nivalis.

\section{VALIDATIONS AND TYPIFICATIONS IN THE ENTOPHYSALIDETEA DEUSTAE}

The Entophysalidetea comprises the marine photophytic algal vegetation on hard substrates in lower supralittoral and upper parts of eu-littoral level. Unfortunately in the description expressis verbis, the association Lithophylletum lichenoidi, was chosen as type of the class (GiacCONE \& al., 1993) hence rendering the class invalid according to the ICPN. Here we provide an ICPN-conform typification. 
This class includes the Pleurocapsetalia gloeocapsoidis Ercegovic 1932 in the supralittoral zone of the Atlantic and the Mediterranean (with two alliances), the Bangietalia atropurpureae Giaccone in Giaccone et al. 1993 in the upper eu-littoral and the Neogoniolitho notarisi-Nemodermetalia tingitani Molinier 1960 in the lower eu-littoral of the Mediterranean (one alliance each), the Fucetalia vesiculosi with two new alliances for the upper and lower eu-littoral of the Atlantic and, finally the Dalmatelletalia polyformis Ercegovic 1932 and the Hyelletalia caespitosae Ercegovic 1932 described from limestone coasts of the Eastern Mediterranean (with two alliances each). Several of the characteristic species of the two orders by ERCEGOVIC (1932) are also known from the Atlantic limestone coasts and it is possible that these poorly-known syntaxa are not exclusively Mediterranean.

\section{Entophysalidetea deustae Giaccone class. nov. hoc loco}

VALIDATED NAME: Entophysalidetea deustae Giaccone in Giaccone et al. 1993 (GIACCONE \& al., 1993: 262, 270) [Art. 5].

SynONYMS: Chthamaletea Giaccone 1965 [Art. 2c], Melarphetea neritoidis Giaccone 1965 p.p. [Art. 2c], Dictyoto dichotomae-Laurencietea pinnatifidae Julve 1992 p.p. [Art. 5], Peyssonnelio dubyi-Lithophylletea incrustantis Julve 1992 p.p. [Art. 2b], Fucetea Golub et al. 2003 [Arts. 2b, 5], Dictyoto dichotomaeOsmundeetea pinnatifidae Julve ex Julve et Manneville 2006 p.p. [Art. 3i].

Type: Holotypus hoc loco: Ralfsietalia verrucosae Giaccone 1993 (GIACCONE \& al., 1993: 269, 281).

CHARACTER TAXON OF THE Class: Brachytrichia quoyi.

Fucetalia vesiculosi Julve ordo nov. hoc loco (Entophysalidetea deustae)

VALIDATED NAME: Fucetalia vesiculosi Julve 1992 (Julve, 1992: 566-567) [Art. 2b].
SYNONYMS: Fucetalia Hadač in Klika 1948 [Art. 2b], Fucetalia Golub et al. 2003 [Arts. 2b, 5], Ascophyllo nodosi-Fucetalia serrati Julve et Manneville 2006 [Art. 3i].

TYPE: Holotypus hoc loco: Ascophyllion nodosi Julve in Bültmann et al. 2015 (see below).

CHARACTER TAXA OF THE ORDER: Cladophora rupestris and the character taxa of the alliances, e.g. Ascophyllum nodosum, Fucus serrratus, F. vesiculosus, Pelvetia canaliculata.

\section{Ascophyllion nodosi Julve all. nov. hoc loco}

(Fucetalia vesiculosi, Entophysalidetea deustae)

VAlidated nAmE: Ascophyllion nodosi Julve et Manneville 2006 (Julve \& MANNEVILLE, 2006: 222-223. Table 1) [Art. 5].

Synonyms: Dictyosiphonion foeniculacei Du Rietz 1941 [Art. 2b], Dictyosiphonion Du Rietz ex Klika 1948 [Art. 2b], Pelvetion canaliculatae Hadač in Klika 1948 [Art. 2b], Fucion Golub et al. 2003 [Arts. 2b, 5].

TYPE: Holotypus hoc loco: Ascophylletum nodosi den Hartog 1959 (DEN HARTOG, 1959: 199-204).

Character TAXA OF THE ALliance: Ascophyllum nodosum, Bostrychia scorpioides, Catenella caespitosa, Fucus ceranoides, F. spiralis, F. vesiculosus, Pelvetia canaliculata, Vertebrata lanosa.

\section{VALIDATIONS IN THE CYSTOSEIRETEA}

The Cystoseiretea Giaccone 1965 comprises the Mediterranean Cystoseiretalia Molinier 1960, the Atlantic Laminarietalia hyperboreae Julve 1992, and the thio-nitrophytic Ulvetalia lactucae Molinier 1960 occurring in in both Atlantic Ocean and the Mediterranean Sea.

The Laminarietalia include the Laminarion saccharinae Julve 1992 in protected coastal habitats and the Laminarion hyperboreae in more dynamic habitats. Julve \& MANNEVILLE (2006) used the name Cystoseirion tamariscifoliae, but as no such species occurs in the relevés of the original diagnosis, the name Laminarion hyperboreae, 
was chosen instead. JULVE \& MANNEVILLE (2006) described the Alario esculenti-Himanthalietum elongatae and the Saccorhizo polyschidiLaminarietum hyperborea by presenting only a synoptic table. The alliance and both associations are validated here:

\section{Laminarion hyperboreae Julve all. nov. hoc loco}

(Laminarietalia hyperboreae, Cystoseiretea)

VAlidated NAME: Cystoseirion tamariscifoliae Julve 1992 (JuLVE, 1992: 568) [Art. 2b]

SynONYM: Cystoseirion baccatae Julve 1992 [Art. 2b].

TyPe: Holotypus hoc loco: Saccorhizo polyschidi-Laminarietum hyperboreae Julve in Bültmann et al. 2015 (see below).

Character taxa of the Alliance: Alaria esculenta, Calliblepharis jubata, Chylocladia verticillata, Dilsea carnosa, Halopteris scoparia, Himanthalia elongata, Laminaria digitata, L. hyperborea, Lomentaria clavellosa, Saccorhiza polyschides.

Saccorhizo polyschidi-Laminarietum hyperboreae Julve ass. nov. hoc loco

( Laminarion hyperboreae, Laminarietalia hyperboreae, Cystoseiretea)

VAlidated NAME: Saccorhizo polyschidiLaminarietum hyperboreae Julve et Manneville 2006 (Julve \& Manneville, 2006: 225. Table 1) [Art. 2b].

TYPe: Holotypus hoc loco: JULVE \& MANNEVILLE (2006) included a column of a synoptic table, but the full table was presented online. Here the relevé 235 had been extracted from that source is presented as the holotype:

France, Bretagne, upper infralittoral, growing on rock face, exposed to wave action (cover scale: + to 5): Laminaria hyperborea 4, Chondrus crispus 2, Ellisolandia elongata 2, Laminaria digitata 2, Palmaria palmata 2, Saccorhiza polyschides 2, Callophyllis laciniata 1, Corallina officinalis 1, Cryptopleura ramosa
1, Dilsea carnosa 1, Furcellaria lumbricalis 1, Halurus flosculosus 1, Membranoptera alata 1, Osmundea pinnatifida 1, Calliblepharis jubata + , Callithamnion tetragonum + , Ceramium virgatum +, Chondracanthus acicularis +, Claviclonium ovatum +, Codium tomentosum + , Desmarestia aculeata + , Gelidium pulchellum + , Halurus equisetifolius + , Heterosiphonia plumosa + , Plocamium cartilagineum + .

CHARACTER TAXA OF THE ASSOCIATION: Calliblepharis jubata, Dilsea carnosa, Laminaria hyperborea, Saccorhiza polyschides.

\section{Alario esculenti-Himanthalietum elongatae Julve ass. nov. hoc loco. \\ (Laminarion hyperboreae, Laminarietalia hyperboreae, Cystoseiretea)}

VALIDATED NAME: Alario esculentiHimanthalietum elongatae Julve \& Manneville 2006 (Julve \& Manneville, 2006: 225. Table 1) [Art. 2b].

TYPe: Holotypus hoc loco: Julve \& Manneville (2006) include a column of a synoptic table, but the full table is given online only. Here the relevé 78 is selected from from that source as the holotype: France, Bretagne, eu- to infralittoral, growing on rock exposed to strong wave action (cover scale: + to 5): Himanthalia elongata 4, Corallina elongata 3, Mastocarpus stellatus 3, Osmundea pinnatifida 2, Alaria esculenta 1, Bifurcaria bifurcata 1, Boergeseniella thuyoides 1, Chondrus crispus 1, Chylocladia verticillata 1, Laminaria digitata 1, Cladophora rupestris + , Codium tomentosum +, Lomentaria articulata +, Lomentaria clavellosa + , Polysiphonia stricta + . Character taXa of the association: Alaria esculenta, Chylocladia verticillata, Halopteris scoparia, Himanthalia elongata, Lomentaria clavellosa.

\section{A NEW ORDER AND ALLIANCE IN THE LITHOPHYLLETEA SOLUTI}

The class Lithophylletea soluti Giaccone 1965 includes two Mediterranean orders 
(Rhodymenietalia ardissonei Augier et Boudouresque 1975 and Lithophylletalia soluti Giaccone 1965) and the Atlantic Delesserietalia sanguinei. The validation of the latter is necessary because in JULVE (1992), the class, the order and the associations were listed without the name of an alliance and JULVE \& MANNEVILLE (2006) described the alliance with one invalid association only.

\section{Delesserietalia sanguinei Julve ordo nov. hoc loco \\ (Lithophylletea soluti)}

VALIDATED NAME: Delessertietalia sanguinei Julve 1992 (JuLVE, 1992: 569-570) [Art. 2b].

TyPe: Holotypus hoc loco: Delesserion sanguineae Julve in Bültmann et al. 2015 (see below). CHARACTER TAXA OF THE ORDER: Agarum clathratum, Alaria esculenta, Bonnemaisonia hamifera, Calliblepharis ciliata, Callithamnion tetricum, Chondrus crispus, Coccotylus truncatus, Delesseria sanguinea, Fimbrifolium dichotomum, Gigartina pistillata, Heterosiphonia plumosa, Membranoptera alata, Odonthalia dentata, Phycodrys rubens, Phyllophora pseudoceranoïdes, Plumaria plumosa, Polysiphonia arctica, Ptilota gunneri, Stenogramma interruptum.

\section{Delesserion sanguinei Julve all. nov. hoc loco} (Delesserietalia sanguinei, Lithophylletea soluti)

VAliDated name: Delesserion sanguineae Julve et Manneville 2006 (Julve \& ManNeville, 2006: 225-226. Table 1) [Art. 2b].

SYNONYM: Polysiphonion arcticae Hadač in Klika 1948 [Art. 2b].

Type: Holotypus hoc loco: Delesserietum sanguineae Julve in Bültmann et al. 2015 (see below). CHARACTER TAXA OF THE ALLIANCE: the same as for the order (see above).

\section{Delesserietum sanguineae Julve ass. nov. hoc loco}

(Delesserion sanguinei, Delesserietalia sanguinei, Lithophylletea soluti)
VAlidATED NAME: Heterosiphonio plumosiDelesserietum sanguineae Julve et Manneville 2006 (Julve \& Manneville, 2006: 226. Table 1) $[$ Art. 2b].

TYPe: Holotypus hoc loco: Julve \& MANNEVILLE (2006) included a column of a synoptic table; full relevé table was presented online and here we select the relevé 133 from this source and present as the holotype:

France, Bretagne, eu-littoral, on rock in a shaded pool, exposed to wave action (cover scale: + to 5): Phyllophora crispa 4, Plumaria plumosa 3, Corallina officinalis 2, Ceramium virgatum 1, Laminaria digitata 1, Delesseria sanguinea + .

Character tAXA OF THE ASSOCIATION: Apoglossum ruscifolium, Delesseria sanguinea, Halurus equisetifolius, Heterosiphonia plumosa, Phyllophora crispa, Pleonosporium borreri, Plumaria plumose.

\section{VALIDATION IN THE CAULERPETEA RACEMOSAE}

The Caulerpetea racemosae includes one order and one alliance with five associations dominated by species of Caulerpa (Caulerpetum racemosae Giaccone et Di Martino 1995, Caulerpetum scalpeIIiformis Mayhoub ex Giaccone \& Di Martino 1995, Caulerpetum mexicanae Giaccone et Di Martino 1995, Caulerpetum taxifoliae Di Martino et Giaccone 1997 and Caulerpetum proliferae Giaccone et Di Martino 1997). In the original description of the higher syntaxa, the genus name was used without epithet and hence is not possible to decide, which of several Caulerpa were the name-giving species.

\section{Caulerpetea racemosae Giaccone et Di Martino class. nov. hoc loco}

Validated name: Caulerpeteae Giaccone et Di Martino 1997 (Giaccone \& Di Martino, 1997: 6) $[$ Art. 3g] 
Type: Holotypus hoc loco: Caulerpetalia racemosae Giaccone et Di Martino in Bültmann et al. 2015 (see below).

Character tAXa of the Class: Caulerpa prolifera, C. racemosa.

\section{Caulerpetalia racemosae Giaccone et Di Martino ordo nov. hoc loco \\ (Caulerpetea racemosae)}

VAlidated name: Caulerpetalia Giaccone et Di Martino 1997 (Giaccone \& Di MARTINO, 1997: 6) [Art. 3g].

Type: Holotypus hoc loco: Caulerpion racemosae Giaccone et Di Martino in Bültmann et al. 2015 (see below).

CHARACTER TAXA OF THE ORDER: the same as for the Caulerpetea racemosae (see above).

\section{Caulerpion racemosae Giaccone et Di Martino all. nov. hoc loco}

(Caulerpetalia racemosae, Caulerpetea racemosae)
VALIDATED nAmE: Caulerpion Giaccone et Di Martino 1997 (Giaccone \& Di Martino, 1997: 6) [Art. 3g].

TYPE: Holotypus hoc loco: Caulerpetum racemosae Giaccone et Di Martino 1995 (GIACCONE \& Di Martino, 1995: 66, 68-70).

CHARACTER TAXA OF THE ALLIANCE: the same as for the Caulerpetea racemosae (see above).

\section{ACKNOWLEDGEMENTS}

First of all, the authors want to thank Laco Mucina, Perth, for his long-standing support. Particular thanks are also due to Jean-Paul Theurillat, Chambésy and Jens Pallas, Münster, for nomenclatural advice and Federico Fernández-González, Toledo, for the Spanish translations.

\section{REFERENCES}

Abbassi Maaf, L. \& Roux, C. —1987— Les peuplements lichéniques corticoles de la chênaie verte: étude comparée de la gardiole de Rians et de l'île de Port-Cros (Var) - Bull. Soc. Linn. Provence 38: 189-245.

Asta, J. \& Roux, C. —1977- Étude écologique et phytosociologique de la végétation lichénique des roches plus ou moins décalcifiées en surface aux étages subalpin et alpin des Alpes françaises - Bull. Mus. Hist. Nat. Marseille 37: 23-81.

Asta, J., Clauzade, G. \& Roux, C. -1973a-Étude de quelques groupements lichéniques saxicoles-calcicoles du parc national de la Vanoise - Trav. Sci. Parc Nat. Vanoise 3: 73-104.

Asta, J., Clauzade, G. \& Roux, C. $-1973 b-$ Stenhammarelletum turgidae Hertel ass. nov. - Rev. Fac. Ci. Lisboa 2. Ser. C 17(2): 543-567.

Barkman, J.J. - 1958 - Phytosociology and ecology of cryptogamic epiphytes - Van Gorcum, Assen.

Barkman, J.J. —1973 - Synusial approach to classification - In: Whittaker, R.H. (Ed.). Ordination and classification of vegetation. Pp. 436-491. Dr W. Junk Publishers, The Hague.

Bomfleur, B., Krings, M. \& Kerp, H. -2010 - Thalloid organisms and the fossil record. New perspectives from the Transantarctic Mountains — Plant Sign. Behav. 5: 293-295.
Brand, F. -1925- Analyse der aerophilen Grünalgenanflüge, insbesondere der proto-pleurococcoiden Formen - Arch. Protist. 52: 265-354.

Braun-Blanquet, J. - 1964- Pflanzensoziologie. Grundzüge der Vegetationskunde 3. Aufl. - SpringerVerlag, Wien.

Bricaud, O. -2004 - Les peuplements lichéniques corticoles sciaphiles et foliicoles méditerranéens de la France méridionale - Bull. Soc. Linn. Provence, Num. Spéc. 12: 1-324.

Büdel, B. \& Henssen, A. —1988 - Trebouxia aggregata und Gloeocapsa sanguinea, Phycobionten von Euopsis granatina (Lichinaceae) - Plant Syst. Evol. 158: 235-241.

Bültmann, H. - 2005- Syntaxonomy of arctic terricolous lichen vegetation, including a case study from Southeast Greenland - Phytocoenologia 36: 909-949.

Bültmann, H. - 2010 - Diversity and similarity of lichen floras of countries along a south-north gradient from Italy to Greenland - Ann. Bot. S.N. 1(1): 1-9.

Creveld, M. - 1981 - Epilithic lichen communites in the alpine zone of southern Norway - Bibl. Lichenol. 17: 1-288.

Den Hartog, C. - 1959 - The epilithic algal communities occuring along the coast of the Netherlands - Wentia 1: $1-241$. 
Egea, J.M. —1989 - Las comunidades liquénicas saxícolas, ombrofobas, litorales, del suroeste de Europa y Norte de Africa (Roccelletea phycopsis classis prov.) Stud. Geobot. 9: 73-152.

Egea, J.M. \& Llimona, X. —1984- Las comunidades liquénicas saxícolas, ombrofobas de la costa del SE. de España comprendidas entre el Penyal d'Ifach (Alicante) y Almería - Collect. Bot. 15: 205-219.

Ercegovic, A. -1932- Ecološke i sociološke studije î litofitskim cijanoficejama sa Jugoslavenske obale Jadrana (Ecological and sociological studies on lithophytic cyanophytes on the Yugoslavian coast of the Adriatic Sea) - Rad Jugoslav. Akad. Znanosti i Umjetnosti 244: 129-220. (in Croatian).

Fogg, G. - 1967- Observation on the snow algae of the South Orkney Islands - Phil. Trans. Royal Soc. London, Series B 252: 279-287.

Frey, E. —1923 - Die Berücksichtigung der Lichenen in der soziologischen Pflanzengeographie, speziell der Alpen — Verh. Nat. Ges. Basel 35: 303-320.

Gärtner, G. \& Ingolić, E. -1989- Ein Beitrag zur Kenntnis von Apatococcus lobatus (Chlorophyta, Chaetophorales, Leptosiroideae) — Plant Syst. Evol. 164: 133-143.

Gärtner, G. —1994 - Zur Taxonomie aerophiler grüner Algenanflüge an Baumrinden — Ber. Nat.-Med. Ver. Innsbruck 81: 51-59.

Giaccone, G. \& Di Martino, V. — 1995 — La vegetazione a Caulerpa racemosa (Forsskäl) C. Agardh nella Baia di S. Panagia (Sicilia Sud-Orientale) - Boll. Accad. Gioenia Sci. Nat. 28: 59-73.

Giaccone, G. \& Di Martino, V. —1997- Inquadramento fitosociologico ed ecologia della vegetazione a Caulerpe in Mediterraneo - In: Cossul, A. \& Meloni, M.M. (Eds.). Atti del Convegno S.O.S. Caulerpa? Introduzione di nuove specie nel Mediterraneo e compatibilità con quelle presenti. Cagliari, 25.11.1996. Pp. 69-86. Poseidon Publ., Cagliari.

Giaccone, G., Alongi, G., Cossu, A., Di Geronimo, R. \& Serio, D. - 1993 - La vegetazione marina bentonica del Mediterraneo: I. Sopralitorale e Mesolitorale. Proposte di aggiornamento - Boll. Accad. Gioenia Sci. Nat. 26: 245-291.

Giralt, M. - 1996 - Líquens epífits i contaminació atmosférica a la plana i les serrallades litorals tarragonines Arx. Sec. Ci., Sec. Ci. Biol. 113: 1-528.

Golubić, S. - 1967- Algenvegetation der Felsen. Eine ökologische Algenstudie im dinarischen Karstgebiet Binnengewässer 23: 1-183.

Golubić, S., Pietrini, A.M. \& Ricci, S. - 2015- Euendolithic activity of the cyanobacterium Chroococcus lithophilus Erc. In biodeterioration of the Pyramid of Caius Cestius, Rome, Italy — Int. Biodet. Biodegr. 100: 7-16.

Gustavs, L. - 2010 - Biodiversity and ecophysiology of aeroterrestrial green algae (Trebouxiophyceae, Chlorophyta) - Thesis, Univ. Rostock, Rostock.
Hilitzer, A. - 1925 - Étude sur la végétation epiphyte de la Bohême - Spisy vidávané Přirodovědeckou fakultou Karlovy Univ. 41: 1-202.

Julve, P. - 1992 - Classification phytosociologique des végétations d'algues marines benthiques de France Bull. Soc. Bot. Centre-Ouest N.S. 23: 565-576.

Julve, P. \& Manneville O. - 2006-Contribution à l'étude synusiale des végétations littorales de macroalgues marines des côtes atlantiques françaises - Acta Bot. Gallica 153: 219-234.

Khaybullina, L.S., Sukhanova, N.V., Kabirov, R.R. \& Solomeshch, A.I. -2004- Sintaksonomija soobščestv počvennych vodoroslej južnogo Urala. Čast 1. Sojuz Amphoro-Phormidion all. nov. hoc loco. (Syntaxonomy of soil algae communities in South Ural. I. Alliance Amphoro-Phormidion all. nova hoc loco.) - Algologia 14: 261-276.

Khaybullina, L.S., Sukhanova, N.V., Kabirov, R.R. \& Solomeshch, A.I. - 2005- Sintaksonomija soobščestv počvennych vodoroslej južnogo Urala. Čast 2. Sojuz Klebsormidio flaccidi-Myrmecion biatorellae all. nova. (Syntaxonomy of soil algae communities in South Ural. II. Alliance Klebsormidio flaccidi-Myrmeñion biàtorellae all. nova.) - Algologia 15: 86-100.

Khaybullina, L.S., Sukhanova, N.V., Kabirov, R.R. \& Solomeshch, A.I. - 2005a- Syntaxonomy of communities of soil algae in the Southern Ural. 3. Class Bracteacocco-Hantzschietea cl. nov. - Int. J. Algae 7: 281-298.

Klement, O. — 1955 - Prodromus der mitteleuropäischen Flechtengesellschaften - Feddes Repert. Spec. Nov. Regni Veg., Beit. Veg. 1: 1-194.

Klement, O. - 1965- Zur Kenntnis der Flechtenvegetation der Kanarischen Inseln - Nova Hedwigia 9: 503-582.

Klika, J. —1948 - Rostlinná sociologie. (Plant sociology.) - Melantrich, Praha. (in Czech).

Klika, J. \& Hadač, E. —1944- Rostlinná společenstřední Evropy. (Plant communities of Central Europe.) Př́roda (Praha) 36: 249-259. (in Czech).

Kol, E. — 1942 - The snow and ice algae of Alaska Smithson. Misc. Collect. 101(16): 1-36.

Laundon, J.R. - 1985- Desmococcus olivaceus. The name of the common subaerial green alga - Taxon 34: 671-672.

Llimona, X. \& Egea, J.M. —1984- La vegetación liquénica saxicola de los volcanes del Mar Menor (Murcia, SE de España) - Butll. Inst. Cat. Hist. Nat. 51, Sec. Bot. 5: 77-99.

Llimona, X. \& Egea, J.M. —1985- Las comunidades liquenicas de las superficies de escorrentia de las rocas siliceas mediterraneas - An. Jard. Bot. Madrid 41: 429-444.

Margalef, R. - 1944 - Datos para la flora algológica de nuestras aguas dulces — Publ. Inst. Bot. 4(1): 1-130.

Margalef, R. - 1949 - Las asociaciones de algas ei las aguas dulces de pequeño volumen del noreste de España — Vegetatio 1: 258-284. 
Margalef, R. — 1950 - Datos para la hidrobiología de la cordillera cantábrica, especialmente del macizo de los Picos de Europa - Publ. Inst. Biol. Apl. 7: 37-76.

Margalef, R. —1951 — Regiones limnológicas de Cataluña y ensayo de sistematización de las asociaciones de algas - Collect. Bot. 3: 43-67.

Marstaller, R. - 2006 - Syntaxonomischer Konspekt der Moosgesellschaften Europas und angrenzender Gebiete - Haussknechtia Beiheft 13: 1-192.

Messikommer, E. —1927- Biologische Studien im Torfmoor von Robenhausen unter besonderer Berücksichtigung der Algenvegetation - Mitt. Bot. Mus. Univ. Zürich 122: 1-171.

Michael, E., Henning, B. \& Kreisel, H. -1985Handbuch für Pilzfreunde. IV. Band. BlätterpilzeDunkelblättler — G. Fischer Verlag, Stuttgart.

Möller, B. \& Pankow, H. -1981- Algensoziologische und saprobiologische Untersuchungen an Vorflutern der Elbe — Limnologica 13: 291-350.

Möller, B. — 1977- Algensoziologische und saprobiologische Untersuchungen an Vorflutern der Elbe Thesis, Univ. Rostock, Rostock.

Moreno, P.P. \& Egea, J.M. — 1991— Biología y taxonomía de la familia Lichinaceae, con especial referencia a las especies del S.E. español y Norte de África - Col. Blanca 19: 1-87.

Mulec, J. \& Kosi, G. — 2009 — Lampenflora algae and methods of growth control — J. Cave Karst Stud. 71: 109-115.

Nowak, J. —1960 - Naskalne zespoły porostów Wyżyny Krakowsko-Czę stochowskiej. (Saxicolous associations of lichens of the Cracow-Czestochowa Upland.) Fragmenta Flor. Geobot. 6: 323-392. (in Polish).

Ochsner, F. - 1928 - Studien über die EpiphytenVegetation der Schweiz - Jahrb. St. Gallischen Nat. Ges. 63: 1-108.

Pankow, H. - 1980- Die benthischen Kieselalgengesellschaften der Boddengewässer des Darß und des Zingst (südliche Ostsee) — Wiss. Z. WilhelmPieck-Univ. Rostock, Mat.-nat. Reihe 29: 131-37.

Pankow, H., Haendel, D. \& Richter, W. -1991- Die Algenflora der Schirmacheroase (Ostantarktika) Nova Hedw. Beih. 103: 1-197.

Paus, S. M. - 1997- Die Erdflechtenvegetation Nordwestdeutschlands und einiger Randgebiete - Bibl. Lichenol. 66: 1-222.

Pirk, W. \& Tüxen, R. -1955- Das Coprinetum ephemeroidis, eine Pilzgesellschaft auf frischem Mist der Weiden im mittleren Wesertal- Mitt. Flor.-soziol. Arbeit. N.F. 1: 1-7.

Pirk, W. \& Tüxen, R. — 1957- Das Trametetum gibbosae, eine Pilzgesellschaft modernder Buchenstümpfe Mitt. Flor.-soziol. Arbeit. N.F. 6-7: 120-126.

Remias, D., Wastian, H., Lütz, C. \& Leya, T. - 2013Insights into the biology and phylogeny of Chloromonas polyptera (Chlorophyta), an alga causing orange snow in Maritime Antarctica - Antarct. Sci. 25: 648-656.
Rindi, F. - 2007- Diversity, distribution and ecology of green algae and cyanobacteria in urban habitats - In: Seckbach, J. (Ed.). Algae and cyanobacteria in extreme environments. Pp. 619-638. Springer, Dordrecht.

Rindi, F. \& Guiry, M.D. -2003- Composition and distribution of subaerial algal assemblages in Galway City, western Ireland - Cryptogamie Algol. 24: 245-267.

Roux, C. - 1981-Étude écologique et phytosociologique des peuplement lichéniques saxicoles-calcicoles du sudest de France - Bibl. Lichenol. 15: 1-557.

Samad, L.K. \& Adhikary, S.P. — 2008 - Diversity of Micro-algae and Cyanobacteria on Building Facades and Monuments in India - Algae 23: 91-114.

Schlüter, M. - 1961 - Die Diatomeen-Gesellschaften des Naturschutzgebietes Strausberg bei Berlin - Int. Rev. Ges. Hydrobiol. 46: 562-609.

Schuhwerk, F. -1986 - Kryptogamengemeinschaften in Waldassoziationen - ein methodischer Vorschlag zur Synthese - Phytocoenologia 14: 79-108.

Täuscher, L. —1981- Untersuchungen zur Art- und Biozönosestruktur des Phytoplanktons des Großen Müggelsees (Berlin) unter Berücksichtigung produktions- und saprobiologischer Aspekte - Thesis, Humboldt Univ., Berlin.

Täuscher, L. -1995- Hydrobotanische und ökologische Untersuchungen an und in Gewässern des nördlichen Elb-Havel-Winkels II. Garzer See und naturnahes Kleingewässer — Untere Havel - Nat. Ber. 4: 3-11.

Täuscher, L. —1997- Hydrobotanische und ökologische Untersuchungen an und in Gewässern des nördlichen Elb-Havel-Winkels IV. Die planktische und benthische Algenbesiedlung der unteren Havel (incl. Gnevsdorfer Vorfluter) - Untere Havel —Nat. Ber. 6-7: 9-15.

Täuscher, L. —1998- Mikroalgengesellschaften der Gewässer Nordostdeutschlands und ihre Nutzung zur Bioindikation - Feddes Repert. 109: 617-638.

Takeuchi, N. - 2001 - The altitudinal distribution of snow algae on an Alaska glacier (Gulkana Glacier in the Alaska Range) - Hydrol. Proc. 15: 3447-3459.

Takeuchi, N. - 2013 - Seasonal and altitudinal variations in snow algal communities on an Alaskan glacier (Gulkana glacier in the Alaska range) - Environ. Res. Lett. 8: 35002-35011.

Von der Dunk, K. - 1978 - Beobachtungen an epiphyllen Moosen - Hoppea 37: 161-178.

Weber, H.E., Moravec, J. \& Theurillat, J.-P. -2000International Code of Phytosociological Nomenclature. 3rd edition - J. Veg. Sci. 11: 739-768.

Wilmanns, O. - 1966- Kryptogamen-Gesellschaften oder Kryptogamen-Synusien? - In: Tüxen, R. (Ed.). Gesellschaftsmorphologie. Pp. 1-7. Dr W. Junk Publ., The Hague.

Wilmanns, O. —1998- Ökologische Pflanzensoziologie — Quelle \& Meyer, Heidelberg. 
Table 1

Classes of the thallophyte syntaxa, contributors (B: bryophytes, L: lichens, A: algae \& cyanobacteria) and their habitat type (Cladonio-Lepidozietea and Desmococcetea olivacei are listed twice).

\begin{tabular}{lll}
\hline Syntaxa & Contributors & Habitat type \\
\hline
\end{tabular}

On Soil

Funarietea hygrometricae

B

Ceratodonto purpurei -

Polytrichetea piliferi

Psoretea decipientis

Hylocomietea splendentis

Cladonio digitatae-

Lepidozietea reptantis

Campylopodetea vaporarii

Bracteacocco minoris-

Hantzschietea amphioxyos

Non-aquatic rock and hard substrate

Racomitrietea heterostichi

Rhizocarpetea geographici

Schistidietea apocarpi

Ctenidietea mollusci

Clauzadeetea immersae

Verrucarietea nigrescentis

Aspicilietea candidae

Porpidietea zeoroidis

Collematetea cristati

Leprarietea chlorinae

Roccelletea phycopsis

Gloeocapsetea sanguineae

Desmococcetea olivacei

\section{Epiphytic}

Neckeretea complanatae

Frullanio dilatatae-

Leucodonteteasciuroidis

Arthonio radiatae-

Lecidelletea elaeochromae

Hypogymnietea physodis

Fellhaneretea bouteillei

Physcietea

Leprarietea candelaris

Cladonio digitatae-

Lepidozietea reptantis

Desmococcetea olivacei

In freshwater, brackish water and on ice

Platyhypnidio-Fontinalietea antipyreticae

Aspicilietea lacustris

Lemaneetea fluviatilis

Stigeoclonietea tenuis

\section{Charetea}

Naviculetea gregariae

Asterionelletea formosae

Mesotaenietea berggrenii habitats with easily accessible nutrients (charcoal, bones, fur, animal droppings)

B\&L dry acid and nutrient poor soil

B\&L subneutral and calcareous soil

B large, competitive bryophytes on dry soil or thin soil layers on boulders

B\&L moist acidic loamy soils and deadwood or other decaying organic matter

B Mediterranean fumaroles

A soil algae vegetation described from the steppe zone of southern Urals

exposed siliceous rocks

exposed siliceous rocks

exposed limestone rock

shaded and rather moist limestone or occasionally calcareous soil

nutrient-poor limestone

nutrient-rich limestone

subalpine and alpine calcareous schists and decalcified limestone with

short-time snow cover

L subalpine and alpine calcareous schists and decalcified limestone with

long-time snow cover

L jelly lichens on calcareous or base-rich rocks in places temporarily inundated by seepage or trickling water

$\mathrm{L} \quad$ acidic rock in sites protected from rain

$\mathrm{L} \quad$ calcareous and subacidic rock in sites protected from rain

A aerophytic microalgae on calcareous rock

A aerophytic microalgae on acidic bark or rock

B\&L large bryophytes and lichens on shaded and thinly soil-covered basic rocks and on bark

B bark and on leaves

L crustose lichens on smooth, neutral to subacidic bark

L acidic nutrient-poor bark

L epiphyllous lichens

L highly nutrient-rich bark

L bark in situations protected from rain

B\&L moist acidic loamy soils and deadwood or other decaying organic matter

A aerophytic microalgae on acidic bark or rock

$\mathrm{B}(\& \mathrm{~L}) \quad$ hard substrate submerged in freshwater

L hard substrate in very clear freshwater

A hard substrate in current or turbulent freshwater

A benthic macroalgae in eutrophic water with green filamentous and yellowgreen siphon algae

submerged stonewort swards in brackish and freshwater water on soft substrate

A benthic microalgae of brackish and freshwater

A planctic microalgae of brackish and freshwater

A permanent snow and ice 


\section{In marine habitats}

Verrucarietea maurae

Entophysalidetea deustae

Cystoseiretea

Lithophylletea soluti

Caulerpetea racemosae
L rocks from supralittoral to the eu-littoral levels just above the algal levels

A rocks of the supra- and eulittoral levels

A well-insolated habitats of infralittoral and circalittoral levels

A shaded habitats of infralittoral and circalittoral levels

A soft substrates at the lower tidal levels of the Mediterranean Sea

\section{Appendix 1: List of taxa (with authorities) used in this paper.}

\section{Lichens}

Acarospora freyi $\mathrm{H}$. Magn.

Acarospora hospitans H. Magn.

Acarospora impressula Th. Fr.

Acarospora scabra (Pers.) Th. Fr.

Adelolecia kolaensis (Nyl.) Hertel et Rambold

Alyxoria mougeotii (A. Massal.) Ertz, Frisch et G. Thor

Alyxoria variiformis (Anzi) Ertz

Alyxoria subelevata (Nyl.) Ertz et Tehler

Anema decipiens (A. Massal.) Forssell

Anema nummularium (Dufour ex Durieu et Mont.) Nyl. ex

Forssell

Aspicilia candida (Anzi) Hue

Aspicilia mashiginensis (Zahlbr.) Oxner

Aspicilia permutata (Zahlbr.) Clauzade et Rondon

Aspicilia polychroma Anzi subsp. polychroma chemotype verruculosa

Bacidia fraxinea Lönnr.

Bacidia rubella (Hoffm.) A. Massal.

Bacidina phacodes (Körb.) Vězda

Bactrospora patellarioides (Nyl.) Almq.

Bellemerea subcandida (Arnold) Hafellner et Cl. Roux

Biatoridium monasteriense J. Lahm ex Körb.

Caloplaca anchon-phoeniceon Poelt et Clauzade

Caloplaca insularis Poelt

Caloplaca vitellinula (Nyl.) H. Olivier

Candelariella aurella (Hoffm.) Zahlbr.

Candelariella vitellina (Hoffm.) Müll. Arg.

Carbonea atronivea (Arnold) Hertel

Coenogonium luteum (Dicks.) Kalb et Lücking

Collema ryssoleum (Tuck.) A. Schneid.

Dendrographa decolorans (Turner et Borrer ex Sm.) Ertz et Tehler

Diplotomma dispersum (Kremp.) Arnold

Dirina massiliensis Durieu et Mont. morphotype massiliensis

Dirina massiliensis Durieu et Mont. morphotype sorediata

Farnoldia micropsis (A. Massal.) Hertel

Gyalecta derivata (Nyl.) H. Olivier

Gyalecta flotowii Körb.

Gyalecta liguriensis (Vězda) Vězda

Lecania erysibe (Ach.) Mudd

Lecanographa dialeuca (Cromb.) Egea et Torrente

Lecanora diaboli Frey et Poelt

Lecanora dispersa (Pers.) Sommerf.
Lecanora dispersoareolata (Schaer.) Lamy

Lecidea confluescens Nyl.

Lecidea leprosolimbata (Arnold) Lettau ex Poelt

Lecidea speirodes Nyl.

Lecidea tessellata Flörke var. caesia (Anzi) Arnold

Lecidea umbonata (Hepp) Mudd

Lichinella cribellifera (Nyl.) P. P. Moreno et Egea

Lichinella iodopulchra (Couderc ex Croz.) P. P. Moreno et Egea

Metamelanea caesiella (Th. Fr.) Hennssen

Myriospora scabrida (Hedl. ex H. Magn.) K. Knudsen et L. Arcadia

Opegrapha cesareensis Nyl.

Opegrapha lutulenta $\mathrm{Nyl}$.

Paralecanographa grumulosa (Dufour) Ertz et Tehler

Peccania coralloides (A. Massal.) A. Massal.

Peltula euploca (Ach.) Poelt

Peltula omphaliza (Nyl.) Wetmore

Peltula placodizans (Zahlbr.) Wetmore

Phaeophyscia orbicularis (Neck.) Moberg

Physcia caesia (Hoffm.) Fürnr.

Placynthium nigrum (Huds.) Gray

Placynthium subradiatum (Nyl.) Arnold

Placynthium tantaleum (Hepp) Hue

Polyblastia ardesiaca (Bagl. et Carestia) Zschacke

Polyblastia cupularis A. Massal. var. cupularis

Polysporina pusilla (Anzi) M. Steiner ex Kantvilas

Porpidia zeoroides (Anzi) Knoph et Hertel

Psorotichia diffracta (Nyl.) Forssell

Psorotichia frustulosa Anzi

Psorotichia schaereri (A. Massal) Arnold

Pterygiopsis affinis (A. Massal.) Henssen

Rhizocarpon petraeum (Wulfen) A. Massal.

Rhizoplaca melanophthalma (DC.) Leuckert et Poelt

Rinodina confragosa (Ach.) Körb.

Roccella fuciformis (L.) DC.

Roccella phycopsis (Ach.) Ach.

Roccella tinctoria DC.

Roccella tuberculata Vain.

Roccellographa circumscripta (Taylor) Ertz et Tehler Rusavskia elegans (Link) S. Y. Kondr. \& Kärnefelt Teloschistes contortuplicatus (Ach.) Clauzade et Rondon Staurothele sapaudica Asta, Clauzade et Cl. Roux

Staurothele solvens (Anzi) Zschacke

Thelidium ungeri (Flot.) Körb.

Thelopsis isiaca Stizenb. 
Thelopsis rubella Nyl.

Thyrea girardii (Durieu et Mont.) Bagl. et Carestia

Verrucaria fischeri Müll. Arg.

\section{Non-lichenised fungi:}

Aleurodiscus disciformis (DC.) Pat.

Dendrominia dryina (Pers.) Ghobad-Nejhad \& Duhem

Didymosphaeria rubicola Berl.

Navicella pileata (Tode) Fabre

Septobasidium quercinum (De Not. \& Bagl.) Sacc.

\section{Algae \& cyanobacteria:}

Achnanthes brevipes C. Agardh

Actinastrum hantzschii Lagerh.

Agarum clathratum Dumort.

Alaria esculenta (L.) Grev.

Amphora coffaeiformis (C. Agardh) Kütz.

Amphora ovalis (Kütz.) Kütz.

Ancylonema nordenskioeldii Berggr.

Anomoeoneis sphaerophora Pfitzer

Apatococcus lobatus (Chodat) J.B. Petersen

Aphanothece stagnina (Spreng.) A. Braun

Apoglossum ruscifolium (Turner) J. Agardh

Ascophyllum nodosum (L.) Le Jolis

Asterionella formosa Hassall

Bifurcaria bifurcata R. Ross

Boergeseniella thuyoides (Harv.) Kylin

Bonnemaisonia hamifera Har.

Bostrychia scorpioides (Huds.) Mont.

Brachytrichia quoyi Bornet \& Flahault

Brebissonia boeckii (Ehrenb.) E. OMeara

Calliblepharis ciliata (Huds.) Kütz.

Calliblepharis jubata (Gooden. \& Woodw.) Kütz.

Callithamnion tetragonum (With.) Gray

Callithamnion tetricum (Dillwyn) Gray

Callophyllis laciniata (Huds.) Kütz.

Caloneis amphisbaena (Bory) Cleve

Calothrix scopulorum C.Agardh ex Bornet \& Flahault

Catenella caespitosa (With.) L.M. Irvine

Caulerpa prolifera (Forssk.) J.V. Lamour.

Caulerpa racemosa (Forssk.) J. Agardh

Ceramium virgatum Roth

Chlamydomonas nivalis (F.A. Bauer) Wille

Chloromonas nivalis (Chodat) Hoham \& Mullet

Chondracanthus acicularis (Roth) Fredericq

Chondrus crispus Stackh.

Chylocladia verticillata (Lightf.) Bliding

Cladophora rupestris (L.) Kütz.

Claviclonium ovatum (J.V. Lamour.) Kraft \& Min-Thein

Closterium limneticum Lemmerm.

Cocconeis placentula Ehrenb.

Coccotylus truncatus (Pall.) M.J. Wynne \& J.N. Heine

Codium tomentosum Stackh.
Coleofasciculus chthonoplastes (Thur. ex Gomont) M. Siegesmund, J.R. Johans. \& Friedl

Corallina elongata J. Ellis \& Sol.

Corallina officinalis $L$.

Cryocystis brevispina (F.E. Fritsch) E. Kol ex Komárek \& Fott

Cryptopleura ramosa (Huds.) L. Newton

Delesseria sanguinea (Huds.) J.V. Lamour.

Desmarestia aculeata (L.) J.V. Lamour.

Desmococcus olivaceus (Pers. ex Ach.) J.R. Laundon

Desmotetra antarctica (Fritsch) H.U. Ling

Diatoma vulgaris Bory

Dilsea carnosa (Schmidel) Kuntze

Ellerbeckia arenaria (Moore ex Ralfs) R.M. Crawford

Ellisolandia elongata (J.Ellis \& Sol.) K.R. Hind \& G.W. Saunders

Fimbrifolium dichotomum (Lepech.) G.I. Hansen

Fucus ceranoides L.

Fucus serratus L.

Fucus spiralis L.

Fucus vesiculosus $\mathrm{L}$.

Furcellaria lumbricalis (Huds.) J.V. Lamour.

Gelidium pulchellum (Turner) Kütz.

Gigartina pistillata (S.G.Gmel.) Stackh.

Gloeocapsa biformis Erceg.

Gloeocapsa compacta Kütz.

Gloeocapsa kuetzingiana Nägeli ex Kütz.

Gloeocapsa sanguinea (C.Agardh) Kütz.

Gomphonema parvulum (Kütz.) Kütz.

Halopteris scoparia (L.) Sauv.

Halurus equisetifolius (Lightf.) Kütz.

Halurus flosculosus (J. Ellis) Maggs \& Hommers.

Heterosiphonia plumosa (J. Ellis) Batters

Himanthalia elongata (L.) S.F. Gray

Klebsormidium flaccidum (Kütz.) P.C. Silva, K.R. Mattox \& W.H. Blackw.

Laminaria digitata (Huds.) J.V. Lamour.

Laminaria hyperborea (Gunnerus) Foslie

Lomentaria articulata (Huds.) Lyngb.

Lomentaria clavellosa (Lightf. ex Turner) Gaillon

Lyngbya aestuarii Liebman ex Gomont

Mastocarpus stellatus (Stackh.) Guiry

Melosira varians C.Agardh

Membranoptera alata (Huds.) Stackh.

Meridion circulare (Grev.) C. Agardh

Mesotaenium berggrenii (Wittr.) Lagerh.

Micractinium pusillum Fresen.

Microcoleus autumnalis (Gomont) Strunecky, Komárek \& J.R. Johans.

Mucidosphaerium pulchellum (H.C. Wood) C. Bock, Pröschold \& Krienitz

Mycacanthococcus cellaris Hansgirg f. antarcticus Wille

Navicula salinarum Grunow

Navicula tripunctata (O.F. Müller) Bory

Odonthalia dentata (L.) Lyngb.

Oscillatoria limosa C.Agardh ex Gomont 
Oscillatoria tenuis C.Agardh ex Gomont Osmundea pinnatifida (Huds.) Stackh.

Palmaria palmata (L.) F. Weber \& D. Mohr

Pandorina morum (O.F. Müller) Bory

Pediastrum duplex Meyen

Pelvetia canaliculata (L.) Decne. \& Thur.

Phormidium chalybeum (Mert. ex Gomont) Anagn. \& Komárek

Phycodrys rubens (L.) Batters

Phyllophora crispa (Huds.) P.S. Dixon

Phyllophora pseudoceranoïdes (S.G. Gmel.) Newroth \& A.R.A. Taylor

Planothidium lanceolatum (Brébisson ex Kützing) LangeBert.

Pleonosporium borreri (Smith) Nägeli

Plocamium cartilagineum (L.) P.S. Dixon

Plumaria plumosa (Huds.) Kuntze

Polysiphonia arctica J. Agardh

Polysiphonia stricta (Dillwyn) Grev.

Porphyridium purpureum (Bory) K.M. Drew \& R. Ross

Prasiola crispa (Lightfoot) Kütz.
Protoderma cohaerens (Wittrock) Printz

Pseudanabaena limnetica (Lemmerm.) Komárek

Ptilota gunneri P.C. Silva, Maggs \& L.M. Irvine

Raphidonema brevirostre Scherffel

Raphidonema nivale Lagerh.

Rhoicosphenia abbreviata (C. Agardh) Lange-Bert.

Rivularia nitida C. Agardh ex Bornet \& Flahault

Rosenvingiella radicans (Kütz.) Rindi, L.McIvor \& Guiry

Saccorhiza polyschides (Lightf.) Batters

Scenedesmus quadricauda (Turpin) Bréb.

Schizogonium murale Kütz.

Schizothrix heufleri Grunow ex Gomont

Scytonema myochrous C.Agardh ex Bornet \& Flahault

Smithsonimonas abbotii Kol

Spirulina subsalsa Oerst. ex Gomont

Stenogramma interruptum (C. Agardh) Mont.

Trentepohlia abietina (Flotow ex Kütz.) Hansg.

Trentepohlia umbrina (Kütz.) Bornet

Tryblionella hungarica (Grunow) Freng.

Ulnaria ulna (Nitzsch) P. Compère

Vertebrata lanosa (L.) T.A. Chr.

Received: 16 November 2015

Accepted: 23 November 2015 